\title{
Tissue and Plasma Endocan and Endoglin Levels in Patients with Bladder Cancer
}

\author{
Omer Kurt ${ }^{1}$, Cenk Murat Yazici ${ }^{1}$, Murat Aydin ${ }^{2}$
}

\begin{abstract}
Objective: In this study, we aimed to compare plasma endoglin and endocan levels between bladder cancer patients and the control group. The secondary aim of the study was to compare plasma and tissue endoglin and endocan levels between high grade and low grade bladder cancers.

Methods: A total of 36 patients with bladder cancer and 20 patients as control group were included. Eight milliliters of peripheral venous blood sample was taken from both study and control group to determine plasma Endocan and Endoglin levels. A tissue sample of $0.5 \mathrm{~cm}^{3}$ was obtained by cystoscopy and resection of papillary lesion of bladder to determine tissue Endocan and Endoglin levels. Results were compared between bladder cancer and control group.

Result: The mean plasma Endoglin levels were 10.2 (4.5-13.7) ng/mL in low grade bladder cancer, 14.6 (8.4-22.3) ng/mL in high grade bladder cancer and $8.8(6.3-19.4) \mathrm{ng} / \mathrm{mL}$ in the control group. The mean plasma Endocan levels were 520.4 (346.9-647.6) $\mathrm{ng} / \mathrm{L}$ in low grade bladder tumors; 728.5 (311.4-1518.1) $\mathrm{ng} / \mathrm{L}$ in high grade bladder tumors and 479.9 (140.6-864.7) $\mathrm{ng} / \mathrm{L}$ in the control group. Plasma Endoglin level of control group was significantly lower than bladder cancer group $(p<0.001)$. Plasma Endocan level was not different between bladder cancer and control group ( $p=0.117$ ).
\end{abstract}

Conclusions: Plasma Endoglin level was up-regulated in bladder cancer patients whereas plasma Endocan level did not show any difference. J Clin Exp Invest 2016; 7 (2): 195-199

Key words: Bladder cancer, endocan, endoglin, diagnosis

\section{Mesane Kanserli Hastalarda Doku ve Plazma Endokan ve Endoglin Düzeyleri}

\section{ÖZET}

Amaç: Mesane kanseri tanısında ve tedavisinde, invaziv bir yöntem olan sistoskopi altın standart yöntemdir. İnvaziv ve pahalı bir yöntem olması nedeniyle, birçok çalışmada sistoskopiye alternatif yöntemler araştırılmıştır. Bu çalışmada, mesane kanseri ve kontrol grubu hastalarda plazma endoglin ve endokan seviyelerini karşılaştırmayı amaçladık. Çalışmanın ikinci amacı ise düşük derece ve yüksek derece mesane kanserinde plazma ve doku Endoglin ve Endokan seviyelerinin karşılaştırmaktı.

Yöntemler: Mesane kanseri tanısı olan 36 hasta çalışma grubu ve mesane kanseri olmayan 20 hasta kontrol grubu olarak çalışmaya dahil edildi. Plazma endokan ve endoglin seviyelerinin değerlendirilmesi amacıyla hastalardan 8 mililitre periferik venöz kan örneği alındı. Doku endokan ve endoglin seviyelerinin tespit edilebilmesi amacıyla mesanedeki papiller lezyondan sistoskopik görüntüleme altında yapılan rezeksiyon sonrası $0,5 \mathrm{~cm}^{3}$ doku analiz için ayrıldı. Sonuçlar, mesane kanseri ve kontrol grubu arasında karşılaştırıldı.

Bulgular: Ortalama plazma endoglin seviyesi düşük derece mesane kanserinde 10,2 (4,5-13,7), yüksek derece mesane kanserinde 14,6 $(8,4-22,3)$ ve kontrol grubunda 8,8 $(6,3-19,4)$ olarak tespit edildi. Ortanca plazma endokan seviyesi düşük derece mesane kanserinde 520,4 (346,9-647,6), yüksek derece mesane kanserinde 728,5 $(311,4-1518,1)$ ve kontrol grubunda 479,9(140,6-864,7) olarak tespit edildi. Kontrol grubunda plazma endoglin seviyesinin mesane kanseri grubuna göre anlamlı derecede düşük olduğu gözlendi. $(p<0,001)$. Mesane kanseri ve kontrol grubu arasında plazma endokan seviyesi açısından fark olmadığı tespit edildi $(p=0,117)$.

Sonuç: Mesane kanseri hastalarında plazma endoglin seviyesi yükselirken, plazma endokan seviyesinde fark olmadığı gözlenmiştir.

Anahtar kelimeler: Mesane tümörü, endokan, endoglin, tanı

\footnotetext{
${ }^{1}$ Namik Kemal University, School of Medicine, Department of Urology, Tekirdag, Turkey

${ }^{2}$ Namik Kemal University, School of Medicine, Department of Biochemistry, Tekirdag, Turkey
}

Correspondence: Omer Kurt,

Namik Kemal University, School of Medicine, Dept. Urology, Tekirdag, Turkey Email: drkurtomer@gmail.com

Received: 11.04.2016, Accepted: 21.04.2016

Copyright @ JCEI / Journal of Clinical and Experimental Investigations 2016, All rights reserved 


\section{INTRODUCTION}

Bladder cancer is the second most common cancer of the genitourinary system [1]. The majority of patients are over 50 years with the mean age 70 years. The incidence is four times higher in males than in females [2]. Interaction of various genetic and carcinogenic factors play significant role in the etiology. Genetic polymorphism is one of these variables playing a significant role in cancer development and progression [3].

The gold standard procedure for the diagnosis of bladder cancer is cystoscopy. Cystoscopy can establish diagnosis of bladder cancer and useful for treatment of superficial bladder cancers. Histopathological evaluation of tissue is important for pathological staging, determination of treatment strategy and estimation of prognosis [4]. However, cystoscopy is an expensive and invasive technique with high morbidity that results in patient discomfort [5]. Therefore, the development of non-invasive, cost-effective, highly specific/ sensitive screening and diagnostic tests would contribute significantly in the early detection and thus better prognosis of this disease. The researches continue for optimal markers that can be utilized to improve bladder cancer detection and to predict disease recurrence. Although no single marker has yet replaced the need to perform cystoscopy and urine cytology, many tests have been evaluated and are being developed. Two of the molecules investigated for this purpose is Endocan (Endothelial cell-specific molecul-1, ESM-1) and Endoglin (CD105). These two molecules are known to have important roles during endothelial growth, which is an essential factor in the angiogenesis process $[6,7]$. In this study, we aimed to compare plasma Endoglin and Endocan levels between bladder cancer patients and control group. The secondary aim of the study was to compare plasma and tissue Endoglin and Endocan levels between high grade and low grade bladder cancer.

\section{METHODS}

With the approval of local ethical committee, a total of 36 patients who were diagnosed as bladder cancer were enrolled to study from February to August 2015. Twenty patients with no previous diagnosis of bladder cancer were enrolled to study as control group. The patients in control group underwent cystoscopy due to reasons other than bladder cancer (urinary stone, benign prostatic hyperplasia etc.) and had no bladder tumor during cystoscopy. All subject in the study groups were informed about the study and were enrolled once they had given written consent. Exclusion criteria were the presence of cardiovascular disease and any malignancy other than bladder cancer. Patients with active chemotherapy, immunotherapy or radiation and were also excluded from the study.

A total of $8 \mathrm{ml}$. peripheral venous blood sample was taken from both study and control group. It was centrifuged for $15 \mathrm{~min}$ at $4000 \mathrm{xg}$ at $+4^{\circ} \mathrm{C}$ and divided into aliquots and store at $-86^{\circ} \mathrm{C}$ until analysis. A tissue sample of $0.5 \mathrm{~cm} 3$ was obtained by cystoscopy and resection of papillary lesion of bladder. It was directly freezed and stored at $-86^{\circ} \mathrm{C}$ until analysis. Endocan levels in serum samples were measured using ELISA with a "Human ESM-1 ELISA Kit" (Sunred, Lot: 201-12-1978, China), which uses a double antibody sandwich enzyme-linked immunosorbent assay. Measurements were performed by an automated ELISA reader at $450 \mathrm{~nm}$. The results were expressed as nanograms per liter $(\mathrm{ng} / \mathrm{L})$. The characteristics of this kit is given as: Sensitivity $7.5 \mathrm{ng} / \mathrm{L}$, Intra-assay precision $\mathrm{CV}<10 \%$, Inter-assay precision $\mathrm{CV}<12 \%$, detection range $0.25 \mathrm{ng} / \mathrm{L}-70 \mathrm{ng} / \mathrm{L}$. No interference was observed with hemolyzed or hyperlipidemic plasma or serum.

Endoglin levels in serum samples were measured using ELISA with a "Human ESM-1 ELISA Kit" (Sunred, Lot: 201-12-3704, China). Measurements were done by an automated ELISA reader at $450 \mathrm{~nm}$. The results were expressed as nano grams per liter $(\mathrm{ng} / \mathrm{L})$. The characteristics of this kit is given as: Sensitivity $0.25 \mathrm{ng} / \mathrm{L}$, intra-assay precision $\mathrm{CV}<10 \%$, inter-assay precision $\mathrm{CV}<12 \%$, detection range 0.25 $\mathrm{ng} / \mathrm{L}-70 \mathrm{ng} / \mathrm{L}$. No interference was observed with hemolyzed or hyperlipidemic plasma or serum.

\section{Statistical Analyses}

The statistical analysis of data was performed on "SPSS 17.0 for Windows" (SPSS Inc., IL, USA) software. The distribution of data were analyzed by using Shapiro-Wilk test. The Mann Whitney-U test (in heterogeneous groups) and student-t test (in homogeneous groups) was used for two-way comparisons and the correlation assessment was performed by Pearson test.

Descriptive data were expressed as number and "\%" for categorical variables and median (minimum and maximum, $95 \%$ confidence interval $[\mathrm{CI}]$ ) or mean \pm standard deviation for numeric variables. A " $p$ " value less than 0.05 was regarded as significant. 


\section{RESULTS}

There were $28(87.5 \%)$ male and $4(12.5 \%)$ female patients in bladder cancer group whereas there were $15(75 \%)$ male and $5(25 \%)$ female patients in control group. The mean age was $67.7 \pm 10.95$ years and $60.2 \pm 11.2$ years in bladder cancer and the control groups, respectively $(\mathrm{p}=0.836)$. Six $(18.7 \%)$ patients had diabetes mellitus and $5(15.6 \%)$ patients had hypertension in bladder cancer group. Two (10\%) patients had diabetes mellitus and hypertension in control group each. The pathological evaluation of bladder cancer patients showed Ta/low grade in 7 (21.9\%), $\mathrm{Ta} /$ high grade in $3(9.4 \%)$ patients $\mathrm{T} 1 /$ low grade in 9 $(28.1 \%)$ patients, $\mathrm{T} 1 /$ high grade in $5(15.6 \%)$ patients, CIS in $2(6.3 \%)$ patients and T2 in 6(18.7\%) patients.

The mean plasma endoglin levels were $10.2 \mathrm{ng} /$ $\mathrm{ml}(4.5-13.7)$ in low grade bladder cancer, $14.6 \mathrm{ng} / \mathrm{ml}$ (8.4-22.3) in high grade bladder cancer and $8.8 \mathrm{ng} / \mathrm{ml}$ (6.3-19.4) in the control group. Plasma endoglin level of control group was significantly lower than bladder cancer group $(\mathrm{p}<0.001)$. Plasma endoglin level in control group was also significantly lower than both low grade and high grade bladder cancer $(\mathrm{p}=0.016$ and $\mathrm{p}<0.001$, respectively). The difference of plasma endoglin level was also significantly different between high grade and low grade bladder cancer $(\mathrm{p}=0.005)$. Endoglin level in low grade bladder cancer was lower than high grade bladder cancer $(\mathrm{p}=0.006)$. We only able to detect tissue endoglin level in bladder cancer patients and were not able to compare the results with control group because of the ethical responsibilities. The mean tissue Endoglin level was $3.0 \mathrm{ng} / \mathrm{ml}$ (1.4-
4.0) in low grade and $3.8 \mathrm{ng} / \mathrm{ml}(1.9-5.2)$ in high grade bladder cancer. The difference was significant and tissue Endoglin level in low grade bladder cancer was lower than high grade bladder cancer $(\mathrm{p}>0.05)$.

The mean plasma endocan levels were $520.4 \mathrm{ng} / \mathrm{L}$ (346.9-647.6) in low grade bladder tumor, $728.5 \mathrm{ng} / \mathrm{L}$ (311.4-1518.1) in high grade bladder tumor and 479.9 $\mathrm{ng} / \mathrm{L}$ (140.6-864.7) in control group. Plasma Endocan level was not different between bladder cancer and control group ( $p=0.117)$. Among the subgroup analysis we did not find any difference between low grade, high grade and control groups in terms of plasma Endocan levels. The mean tissue endocan level was $204.5 \mathrm{ng} / \mathrm{L}$ (173.8-228.8) in low grade and $235.0 \mathrm{ng} / \mathrm{L}$ (106.6-346.2) in high grade bladder cancer and there was no difference between groups $(p=0.147)$ (Table $1)$.

Table 1. The demographic characteristics of the patients and the control group

\begin{tabular}{lccc}
\hline & $\begin{array}{c}\text { Bladder Cancer } \\
\text { group }\end{array}$ & $\begin{array}{c}\text { Control } \\
\text { group }\end{array}$ & $\mathbf{p}$ \\
\hline Gender (M/F) & $28 / 4$ & $15 / 5$ & 0.334 \\
\hline Age (years) & $67.7 \pm 10.95$ & $60.2 \pm 11.2$ & 0.836 \\
\hline Histopathology & $\mathbf{n}(\%)$ & & \\
\hline Ta/Low Grade & $7(21.9)$ & & \\
Ta/High Grade & $3(9.4)$ & & \\
T1/Low Grade & $9(28.1)$ & & \\
T1/High Grade & $5(15.6)$ & & \\
Carsinoma in-situ & $2(6.3)$ & & \\
T2 & $6(18.7)$ & & \\
\hline
\end{tabular}

Table 2. Plasma and tissue levels of Endocan and Endoglin in bladder cancer and the control group

\begin{tabular}{lcccc}
\hline & $\begin{array}{c}\text { Low Grade } \\
\text { Bladder Cancer }\end{array}$ & $\begin{array}{c}\text { High Grade } \\
\text { Bladder Cancer }\end{array}$ & $\begin{array}{c}\text { Control } \\
\text { Group }\end{array}$ & p \\
\hline Plasma Endocan, median & 520.4 & 728.5 & 479.9 & \multirow{2}{*}{0.117} \\
(min-max) (ng/L) & $(346.9-647.6)$ & $(311.4-1518.1)$ & $(140.6-864.7)$ & \\
Tissue Endocan, median & 204.5 & 235.1 & & 0.147 \\
(min-max) (ng/L) & $(173.75-228.84)$ & $(106.62-346.16)$ & & \\
Plasma Endoglin, median & 10,2 & 14,6 & 8.84 & $<0.001$ \\
(min-max) (ng/mL) & $(4.5-13.7)$ & $(8.42-22.3)$ & $(6.3-19.4)$ & \\
Tissue Endoglin (min-max) & 3.0 & 3,8 & & 0.006 \\
(ng/ml) & $(1.4-4.0)$ & $(1.9-5.2)$ & & \\
\hline
\end{tabular}

\section{DISCUSSION}

Bladder cancer has the highest per patients cost among any malignancy [1]. The direct economic cost of nonmuscle invasive bladder cancer (NMIBC) is primarily related to the need for lifelong cystoscopy examination because of high recurrence rate and possible progression risk [8]. Cystoscopy is an invasive and expensive procedure that may have side effects, such as infections and urethral damage. Cytology can also be used for the diagnosis of bladder cancer with high specific- 
ity but it needs an expert eye and have low sensitivity. Several molecular markers had been studied but there were only few promising molecular markers that may predict recurrence-free survival [9].

Angiogenesis is a key event for many cancer types. This process gives rise to new blood supply for tumor cells to gain enough oxygen and nutrients. Angiogenesis also important for tumor progression and can be a marker for aggressive behaviour [10]. During progression period, tumor tissue grows in size and eventually becomes hypoxic. This activates the hypoxia-inducible factor signaling system, resulting in VEGF secretion from both tumor cells and tumor-associated stromal cells in an attempt to ensure tumor's oxygen requirements. This stage of tumorigenesis may lead to formation of some biomarkers related to angiogenesis. Endocan and Endoglin in the blood vessel endothelium are two markers that are involved in the control of cell proliferation, migration, and capillary tube formation, and play a pro-angiogenic role [7]. Endocan found in vascular tissues, such as capillaries, arterioles and venules, and is expressed in vascular endothelial cells in normal tissues [11,12]. It is highly restricted to endothelial cells, which may contribute to vascular endothelial cells and can be used as a new endothelial cell activation marker $[13,14]$.

Nault et al. reported higher serum Endocan levels in the hepatocellular cancer cases compared to patients with non-cancerous alcoholic cirrhosis. They stated that serum Endocan may be a good marker of angiogenesis and may even be a potential target in the treatment of angiogenesis [14]. Leroy et al. found 3-10 times higher levels of Endocan in patients with renal papillary cancer compared to healthy individuals. They suggested that Endocan might represent a potential test for use in assessing tumor response to antiangiogenic treatments [15]. Another study investigated the relation between tumor invasion and Endocan expression in patients with pituitary adenoma and stated that increasing Endocan was involved in tumor angiogenesis and could be used to show pituitary adenoma invasion of the neighboring cavernous sinus [16]. In addition to these, Endocan expression was found to be increased in tissue samples of patients with ovarian cancer [17]. Roudnicky et al. collected bladder specimens from normal and invasive bladder cancers. Using real time PCR, Endocan expression was shown to be 1000-100,000 times higher in cancerous tissue. In addition, plasma Endocan levels in cases of invasive bladder cancer were also higher than those of healthy individuals. According to their results, they suggested that Endocan could be used as a prognostic marker in cases of invasive bladder cancer [18]. Contrary to these results we did not find any difference between bladder tumor patients and control group in terms of serum ESM-1 level. Even in patients with high grade and low grade bladder cancer, tissue and plasma Endocan levels did not show any difference. There are very limited numbers of studies about this subject so contrary results might be seen in our preliminary study.

Endoglin (CD105) is a hypoxia-inducible protein acting as a receptor for the TGF $\beta$ family of growth factors. It is also associated with angiogenesis and proliferation. The role of Endoglin has been previously studied in bladder cancer $[19,20]$. Santos et al. reported that the presence of angiogenesis in tumor urothelium, which was evaluated as the immunoexpression of Endoglin, was significantly associated with disease recurrence in patients with $\mathrm{pTa}$ and $\mathrm{pT} 1$ bladder cancer [19]. Agrawal et al. reported that the ratio of p53/ Endoglin expression was associated with bladder recurrence in pTa and pT 1 bladder cancer, but that Endoglin alone was not associated with bladder recurrence [20]. Also, in gastric and endometrial cancers, elevated level of Endoglin in blood serum, as well as in urine, can be seen $[21,22]$. Similar results have been reported in lung, prostatic, colorectal and breast cancers [2324]. We also observed significantly higher levels of Endoglin in patients with bladder cancer compared to control group. Both plasma and tissue Endoglin levels was also significantly different between low grade and high grade tumors. This finding may indicate the importance of plasma Endoglin levels for the diagnosis and follow up patients with bladder cancer.

There were several limitations of our study. The main limitation was related with the number of patients in bladder cancer subgroups. There were only 6 patients with muscle invasive bladder cancer so we were not able to make any conclusion about the efficiency of Endocan and Endoglin levels between non-muscle invasive and muscle invasive bladder cancer. Another limitation was related with tissue sample comparison. We did not collect any tissue sample from control group because of the ethical responsibilities. For that reason we could not compare the tissue Endocan and Endoglin levels between bladder cancer patients and control group.

While plasma Endoglin level was up-regulated in bladder cancer patients, plasma Endocan level did not show any difference. Plasma and tissue Endoglin 
levels were also up-regulated in high grade bladder cancer whereas both plasma and tissue Endocan levels were consistent in low grade and high grade bladder cancers. We found promising results in plasma and tissue Endoglin levels for the diagnosis of bladder cancer. However, further studies are needed to investigate the importance of Endocan and Endoglin mediated pathways in bladder cancer and whether these can be used as a target for anti-angiogenic therapy for bladder cancer.

\section{Acknowledgement}

The authors declare that they have no conflict of interest and no competing financial interests exist. There is no funding for the study. All procedures performed in studies involving human participants were in accordance with the ethical standards of the institutional and/or national research committee and with the 1964 Helsinki declaration and its later amendments or comparable ethical standards.

Declaration of Conflicting Interests: The authors declare that they have no conflict of interest.

Financial Disclosure: No financial support was received.

\section{REFERENCES}

1. Jemal A, Siegel R, Xu JQ, Ward E. Cancer Statistics, 2010. Ca-Cancer J Clin. 2010;60:277-300.

2. Sexton WJ, Wiegand LR, Correa JJ, et al. Bladder cancer: a review of nonmuscle invasive disease. Cancer Control. 2010;17:256-68

3. Franekova M, Halasova E, Bukovska E, et al. Gene polymorphisms in bladder cancer. Urol Oncol. 2008;26:1-8.

4. Cheng L, Montironi R, Davidson DD, Lopez-Beltran A. Staging and reporting of urothelial carcinoma of the urinary bladder. Mod Pathol. 2009;22 Suppl 2:70-95.

5. Falke J, Witjes JA. Contemporary management of low-risk bladder cancer. Nat Rev Urol. 2011;8:42-9.

6. Abid MR, Yi X, Yano K, et al. Vascular endocan is preferentially expressed in tumor endothelium. Microvasc Res. 2006;72:136-45.

7. Fonsatti E, Nicolay HJM, Altomonte M, et al. Targeting cancer vasculature via endoglin/CD105: a novel antibodybased diagnostic and therapeutic strategy in solid tumours. Cardiovasc Res. 2010;86:12-9.

8. Mossanen M, Gore JL. The burden of bladder cancer care: Direct and indirect costs. Curr Opin Urol. 2014;24:487-91.

9. Brems-Eskildsen AS, Zieger K, Toldbod H, et al. Prediction and diagnosis of bladder cancer recurrence based on urinary content of hTERT, SENP1, PPP1CA, and MCM5 transcripts. BMC Cancer. 2010;10:646.

10. R. S. Kerbel, "Tumor angiogenesis, NEJM. 2008; 358: 2039-49.

11. Tsai JC, Zhang J, Minami T, et al.: Cloning and characterization of the human lung endothelial cell specific molecule 1 promoter. J Vasc Res 2002;39:148-159.

12. Aitkenhead M, Wang SJ, Nakatsu MN, et al: Identification of endothelial cell genes expressed in an in vitro model of angiogenesis: Induction of ESM 1, (beta)ig h3, and NrCAM. Microvasc Res 2002;63:159 171.

13. Bechard D, Meignin V, Scherpereel A, et al.: Characterization of the secreted form of endothelial cell specific molecule 1 by specific monoclonal antibodies. J Vasc Res 2000;37:417 425 .

14. Nault JC, Guyot E, Laguillier C, et al. Serum Proteoglycans as Prognostic Biomarkers of Hepatocellular Carcinoma in Patients with Alcoholic Cirrhosis. Cancer Epidem Biomar. 2013;22:1343-52.

15. Leroy X, Aubert S, Zini L, et al. Vascular endocan (ESM1 ) is markedly overexpressed in clear cell renal cell carcinoma. Histopathology 2010;56:180-7.

16. Matano F, Yoshida D, Ishii Y, et al. Endocan, a new invasion and angiogenesis marker of pituitary adenomas. J NeuroOncol. 2014;117:485-91.

17. El Behery MM, Seksaka MA, Ibrahiem MA, et al. Clinicopathological correlation of endocan expression and survival in epithelial ovarian cancer. Arch Gynecol Obstet. 2013;288:1371-6

18. Roudnicky F, Poyet C, Wild P, et al. Endocan is upregulated on tumor vessels in invasive bladder cancer where it mediates VEGF-A-induced angiogenesis. Cancer Res 2013;73:1097-1106.

19. Santos L, Costa C, Pereira S, et al: Neovascularisation is a prognostic factor of early recurrence in $\mathrm{T} 1 / \mathrm{G} 2$ urothelial bladder tumours. Ann Oncol 2003;14:1419-1424.

20. Agrawal U, Mishra AK, Salgia P, et al: Role of tumor suppressor and angiogenesis markers in prediction of recurrence of non muscle invasive bladder cancer. Pathol Oncol Res 2011;17:91-101.

21. Salvesen HB, Gulluoglu MG, Stefansson I, Akslen LA: Significance of CD 105 expression for tumour angiogenesis and prognosis in endometrial carcinomas. APMIS. 2003;111:1011-8

22. Nikiteas NI, Tzanakis N, Theodoropoulos G, et al: Vascular endothelial growth factor and endoglin (CD-105) in gastric cancer. Gastric Cancer. 2007;10:12-7.

23. Saad RS, Liu YL, Nathan G, et al Endoglin (CD105) and vascular endothelial growth factor as prognostic markers in colorectal cancer. Mod Pathol. 2004;17:197-203.

24. Mineo TC, Ambrogi V, Baldi A, et al. Prognostic impact of VEGF, CD31, CD34, and CD105 expression and tumour vessel invasion after radical surgery for IB-IIA non-small cell lung cancer. J Clin Pathol. 2004;57:591-7. 